\title{
FATHOMING THE MUSICAL IDENTITY/IDENTITIES OF JAMES PHILLIPS AKA BERNOLDUS NIEMAND
}

\author{
Caroline van Niekerk \\ Department of Music, University of Pretoria, Pretoria, 0002
}

\section{'n Ondersoek na die musikale identiteit(e) van James Phillips, ook bekend as Bernoldus Niemand}

Literatuur oor musikale identiteit het in die 1990s gedy. Tog is dit opvallend dat tot op datum min mense hulle oor hulle eie musikale identiteite uitgespreek het - musici en navorsers ondersoek en skryf meestal oor ander se musikale identiteite. James Phillips het snerpende lirieke geskryf, wat diep sosiale kommentaar ingesluit het. Hy het 'n formele musiekgraad verwerf en is, as uitvoerder, wyd deur sy eweknieë as die beste 'rock'-musikant van sy dag erken. Tog was hy gesteld op sy privaatheid, en het hom nie maklik uitgespreek as hy direk oor sake uitgevra is nie. Hy het hom beslis nie oor sy eie musikale identiteit uitgespreek nie - behalwe in terme van wat die musiek self te kenne gegee het. Was hy verward? In watter stadiums was hy James Phillips en wanneer was hy sy alter-ego Bernoldus Niemand? Was hy, in die Suid-Afrikaanse konteks, 'n Engelse of 'n (alternatiewe) Afrikaanse musikant? En kan ons moontlik meer hieroor uitvind, meer as 'n dekade na sy voortydige afsterwe? Hierdie artikel poog om dit te doen, gedeeltelik op grond van bepaalde nuwe bronne, asook 'n vergelyking van baie konflikterende sieninge in beskikbare literatuur en uit onderhoude.

Sleutelwoorde: James Phillips, Bernoldus Niemand, musikale identiteit, Voëlvry, alternatiewe Afrikaanse musiek, Suid-Afrikaanse rock-musiek.

Writings on musical identity blossomed in the 1990s, yet it is notable that to date very few people have expressed themselves on their own musical identities - musicians and researchers mostly consider and write about the musical identities of others. Despite writing biting lyrics with deep social commentary, holding a degree in music and being a performer hailed by his peers as the best South African rock musician of his day, James Phillips was a private man, non-committal when asked about things directly. He certainly did not voluntarily express himself publicly, other than through his music itself, on his musical identity. Was he confused? When was he James Phillips and when 
his alter-ego Bernoldus Niemand? Was he an English or an (alternative) Afrikaans South African musician? And can we possibly discover any more about all of this, more than a decade after his premature death? In this article attempts are made to do so, partly based on some new and previously untapped sources, and a comparison of many conflicting views in available literature and from interviews.

Keywords: James Phillips, Bernoldus Niemand, musical identity, Voëlvry, alternative Afrikaans music, South African rock music.

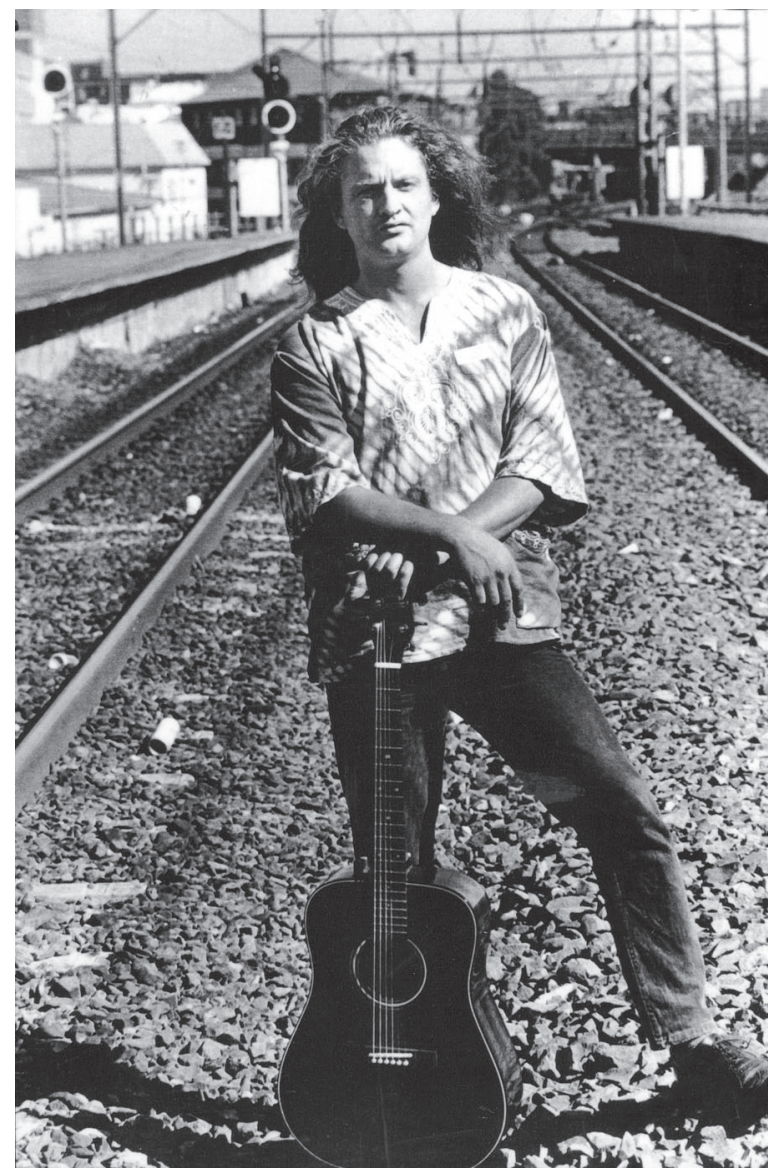

Figure 1: James Phillips in the mid 1980s.

(Photograph: Win Phillips) 


\section{Introduction}

James Phillips (1959-1995) [Fig. 1] was born in Yeoville, Johannesburg into an Englishspeaking, musical South African family, with a mother who sang in operettas and saw to her children's musical education, a Presbyterian cleric father, with a deep appreciation of music, and later one sibling, a younger brother by 8 years, Robin, [Fig. 2] who has developed his international career to the point where he is now Head Vocal Coach and Assistant Artistic Director at the Meiningen State Opera House in Germany.

Major influences on his music were growing up in the working class East Rand town of Springs, receiving his first guitar as a gift at the age of 16, his later 6 months in the defence force (which then became first 1 year and then 2, as happened at that time) and his formal university studies, all against the background of the political situation in Apartheid South Africa. Other musicians of the day talked and still talk/ write enthusiastically about Phillips's influence on them, even describing him as a

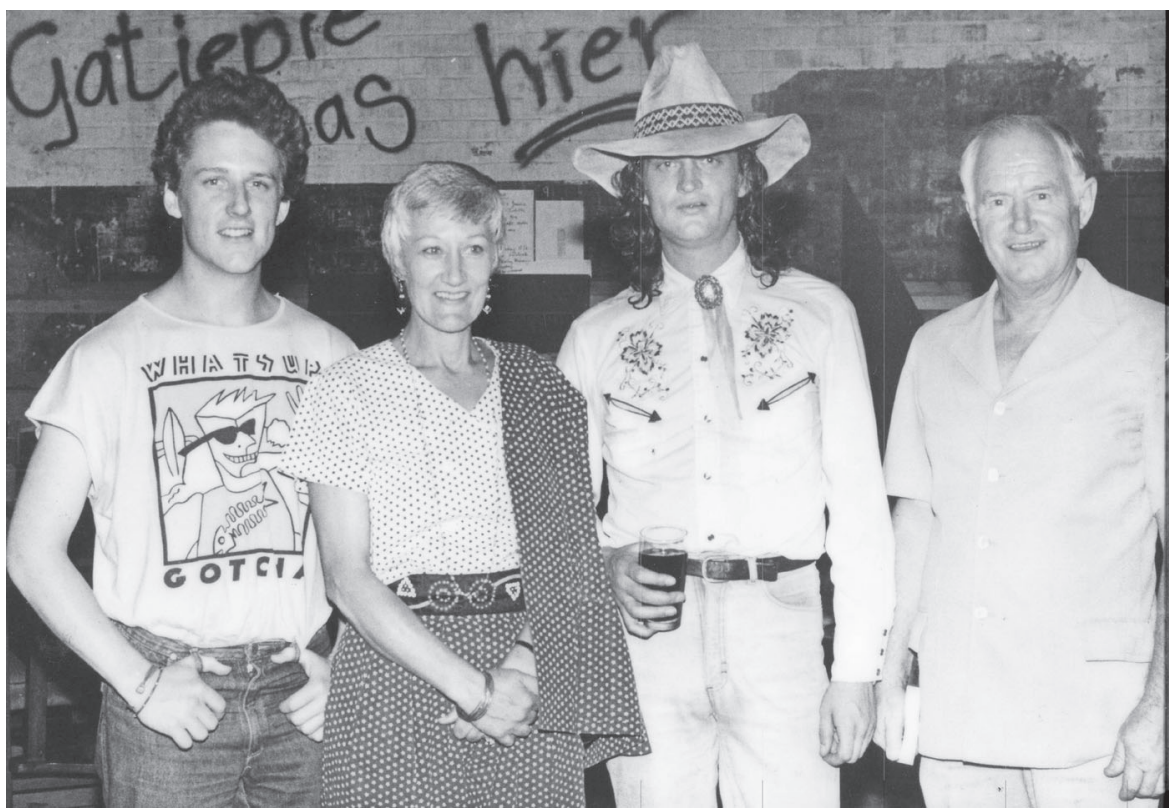

Figure 2: Robin, Win, James and Frank Phillips, Pretoria, ca. 1989

(Photograph: Win Phillips) 
"mentor"; ${ }^{1}$ he does not appear to have had much to say about the reverse. ${ }^{2}$ For him it seemed mostly a question of developing his own music, gathering others around him, forming bands ${ }^{3}$ and having a positive influence. ${ }^{4}$

1 Listen to Koos Kombuis on the DVD accompanying the Voëlvry book (P. Hopkins, Voëlvry (Cape Town, 2006). On p. 101 of this book Hopkins also quotes Kombuis, giving an English version of his words from Seks \& Drugs \& Boeremusiek (Cape Town, 2000), p. 197): "I met Bernoldus Niemand, which I remember well. ...He was one of my first role models along with Breyten Breytenbach... I discovered another side of James Phillips. Together with his band he performed material way different to that on Wie is Bernoldus Niemand? This was his serious music. He was way before his time. In another time, at another place, James Phillips would have been an international star. Just his fucking bad luck that he was born in Springs and just our bad luck that Shifty Records was the smallest record company in the entire world."

2 Fellow BMus students and his lecturers at the University of the Witwatersrand (Wits), contacted by the author, also still all seem to remember Phillips largely positively, as evidenced by the following remarks (in email correspondence to this author, 2007) by well-known South African composer, Carl van Wyk, Phillips's Composition lecturer: “... he challenged the status quo in a refreshing way. There are lots of compliant people in the world and they tend to be very boring - the worker bees, functional and necessary - but James was definitely not one of these! ... My worst nightmare is a compliant James. No, hell, no! ... He was an interesting, talented and offcenter kind of guy, hunting for his own place on the earth ... His strength lay in his anger with the establishment, his ability to capture his feelings in bitingly sarcastic lyrics and matching music, often quite banal on purpose." Even the memory of a person like Mona Naidoo, who worked in the student cafeteria where Phillips apparently spent quite some time, is of a "lovable" character - she stressed this many times in a telephonic discussion (2007-07-26).

The Wits lecturer who perhaps had most to do with Phillips was Mary Rorich. She notes (telephone conversation, 2007-07-22) that she felt quite close to him and had a "huge amount of time for him." Considering that she "mentored him quite a lot", she even considered him a friend, and used adjectives for him such as "charming", "worthwhile", "enquiring", "strongly principled", "sensitive", "enthusiastic" and "humble", with an "amazing openness to people". Rorich described Phillips as a "Romantic artist" who "understood the political value of art; understood what culture meant". "He had this mission - did it irrespective of anything ... he was truly in touch with what things meant $\ldots$ ahead of his time ... had he been ten years down the line ... had Wits been able to accommodate him more ...". She mentioned his "ability to grasp things" ... his "intellectual energy" and the extent to which he was "thrilled by ideas" and how he "participated fantastically in class". John Coulter (personal interview, 2007-07-24), who taught Phillips Choral Conducting, as part of Aural Training, recalls him well, and especially an exceptional Mass which he apparently wrote as a student. However, Coulter views him differently than does Rorich, feeling that he wasn't ahead of his time, but was out and out a product of his time, albeit "politically off track". Thus Coulter does not think, as others have suggested, that Phillips would have enjoyed great recognition today, in different social times. Phillips is not known to have said publicly or written much, if anything, about any of these people.

3 Bernoldus Niemand en die Dagga Rokers, Bernoldus Niemand en die Swart Gevaar, Cherry Faced Lurchers, Corporal Punishment, Illegal Gathering, The Lurchers, etc. - listed here in alphabetical order.

4 Grundlingh notes, for example, that "Bernoldus Niemand was equally outspoken about their perceived influence: 'It was the type of encouragement the reformers required, the knowledge that the laaities (the youth) were with them" (A. Grundlingh, Rocking the boat, International Journal of African Historical Studies 37(30), 2006, pp. 483-514). In Hopkins (P. Hopkins, Voëlvry, p. 215) we read the words of Carl Raubenheimer: “The Lurchers had broken up and he wanted to start a new band to show the laaities how it's done"” and K. Shoemaker (Review of 
So without him available to inform us even a little further, what more can we ascertain about his musicianship and his musical identity? The former is relatively easy, and is written about under the heading "James as artist". The latter is the far more complex question, even with the wisdom of hindsight.

\section{Formative years and experiences and the Corporal Punishment period}

One of the most prolific but dubious exponents on Phillips, his fellow Springs rocker Carl Raubenheimer, noted:

Sure every kid wanted to get the hell out of Springs. But it was also a fantastic place ...Phillips was the most accomplished musician in the town, having been trained by his guitar-and piano-playing 5 mother. Add to that a gravelly voice and anarchic attitude, the essential ingredients for a rocker. But Phillips's life took a turn in 1977, when he was conscripted into the air force in Pretoria. "'It was something he dreaded,' wrote friend and journalist Andrew Donaldson in Style ... 'He once told me all he managed to do properly in the army was open and close a gate.' 6

But national service did much to shape his views and future musical direction. While completing his second year of conscription, he encountered fellow national serviceman Carl Raubenheimer. They had known each other, but not well: Raubenheimer was older, having studied at university before being called up. "Together they decided to take over the world through rock 'n roll, and, with Mark (Bertie) Bennett, formed the snarling skyt rock band Corporal Punishment - going AWOL to perform songs they wrote together,"7 such as the send-up of national service, 'Hou my vas korporaal'8 and the satire of Pretoria, 'Snor City'. Segerman describes the band as "Inspired, but not influenced, by the British punk bands of the late '70s", and claims that "Corporal

Fresh Music: SA artists, 2001. www.rock.co.za/files/jp made) (Accessed 2007-05-17) writes: "Minstrels often provide a voice for people, or put feelings into words. Phillips comes across as a modern troubadour in this sense, perhaps as influential on other musicians as on his audiences."

5 In a personal interview Mrs Phillips modestly noted that her instrumental skills were largely self-taught, that she was more of a singer (musicals and oratorios) and that she believes a lot of the influence on her sons' musical achievements was a result of all the music-making and rehearsals that took place in their home.

6 P. Hopkins, Voëlvry, p. 92.

7 P. Hopkins, Voëlvry, p. 92.

8 Any readers requiring translations of the Afrikaans used in this article are welcome to contact the author for such, as she is a qualified and registered Afrikaans/English translator. 
Punishment reflected the angst and white paranoia of Springs, the typical mining town where Phillips spent his youth."

Although she did use adjectives such as "young, shining with enthusiasm," 10 Muff Andersson also described ${ }^{11}$ Corporal Punishment as a "more militant breed of rock 'n rollers" - the choice of the word "militant" seems unfortunate ${ }^{12}$ in the light of what Grundlingh has noted as Phillips's "clear rejection of the social construction of male gender that forced him to assume the role of a soldier." ${ }^{13}$ Andersson's contention that "The three members of the Corporals met in a mental hospital - or rather, the psychological ward of a military hospital"14 has no basis in fact. Andersson also hardly mentions Phillips as an individual (only in the context of Corporal Punishment), and certainly gives him no special credit, although Carl Raubenheimer does feature specifically in her book. ${ }^{15}$

9 S. Segerman, Fresh Music: SA artists. James Phillips, 2000. www.rock.co.za/files/james (Accessed 2007-05-17)

10 M. Andersson, Music in the Mix: The story of South African popular music (Johannesburg, 1981), p. 137.

11 M. Andersson, Music in the Mix, p. 109.

12 Even though it is not "military", and clearly only refers to an attitude.

13 A.Grundlingh, Rocking the boat, p. 497.

14 M. Andersson, Music in the Mix, p. 137.

15 It needs to be borne in mind that Andersson's book was published in 1981, very early in Phillips's career - Corporal Punishment dissolved at the end of 1980, and many musical developments in Phillips's life occurred thereafter. On the other hand, Raubenheimer, although sometimes being positive about Phillips, appears anxious to take as much credit for himself as possible - he claims, while simultaneously making several very disparaging remarks about Phillips: "We wrote songs together, but James got the credit and did little to dispel the idea they were not his" (see P. Hopkins, Voëlvry, p. 94). There appears to be no substantial evidence, other than his word, that it was not genuinely and largely Phillips doing the writing. Raubenheimer's email (2007-08-14), directly to the author, does nothing to inspire confidence in his holding a balanced view of Phillips: "I don't remember much about the old bastard anymore, but I'll try. James didn't really have an academic slant to his life. There was a fair bit of spirituality, a dash of spirits, and a double dose of duality. I remember him flicking sweat and greasy hair out of his eyes. I remember how jealous I was because he could stick his Lexingtons onto the pointy bits of his lead guitar strings and I had to squish my Chesterfields between the strings and the machineheads of my bass guitar and they always burnt my lips at the end of the song. I remember him smoking the entire weekend's worth of zol at the break at the Hyde Park Hotel gig and disappearing before I could confront him about it. I remember him coming around to bum off his old compadres whenever he was in Skaapstad. I remember that nobody minded whenever he did that. I remember him trying to recreate himself into some kind of ridiculous Tony Cocksian kind of incarnation that never suited him and at which he miserably failed. And I remember me trying to tell him that and I forget what he said about what I said. But it probably was some kind of a Phillips type of smart ass rejoinder. I remember the pain I felt when that stupid Moegoe successfully managed to engineer his own death.

If he'd been born ten years later, he would have been a successful full time musician, but he had no chance in the eighties. His friends knew that there was no discourse with the old 
With particular reference to 'Hou my vas korporaal', Grundlingh has noted ${ }^{16}$ that this was the first time that songs also started to appear in Afrikaans, prompting young men not to march to war but to challenge a system that forced conscription on them ... the appearance of a new Afrikaans cultural dimension." 17

After his discharge from national service Phillips returned to Springs, although in his last year of schooling his family had already moved to Witbank. For the second half of the year, until he went to university in the following year, he worked by day in a motor spares department, and rocked Springs by night with Corporal Punishment. It is interesting that Andersson notes: "The band hails from Springs (the centre of the universe according to bass guitarist Herbie Parkin) and more than anything they'd like to change the position of rock 'n roll in South Africa. They claim to be a 'nonimage' anti- 'product' band." ${ }^{18}$ Although the band actually began while Phillips was still in the army, the strength of the ongoing Springs dynamic is clear. And when Hopkins notes that the "rock 'n roll revolution was in full swing, surprisingly centred in Springs," 19 this is not the reason for Phillips's choosing to be based there - it was largely his presence, and that of Corporal Punishment, that made this the case.

Witty and aggressive, Corporal Punishment refused to do cover versions, and proudly sang songs about white paranoia and suburban life in a distinctive East Rand accent. ${ }^{20}$ With reference inter alia to Corporal Punishment, Andersson wrote:

infrastructure, and so we all entered a cop out world of business and drug addiction. James would have plutzed had he not needed the odd comfortable bed to sleep in. But necessity is the mother of invention and all that....

As far as I'm concerned, that Voëlvry book did me a disservice by misquoting stuff about song writing credits and some other rubbish which has left me feeling a bit pissed off and alienated from my peers, so I'm not too enamoured with the whole episode ... I am impressed that there are people who remember James and who still feel compelled to examine whatever it is that he left behind."

16 A. Grundlingh, Rocking the boat, p. 490.

17 L. Hagen (in Kulturele identiteit: die "Alternatiewe Afrikaanse Beweging" van die Tagtigerjare. M.A.-verhandeling, Randse Afrikaanse Universiteit, 1999, p. 21) explains: "Phillips se werk kan as baanbrekerswerk beskou word omdat veral liedjies soos 'Hou my vas korporaal' ' $\mathrm{n}$ kritiese ingesteldheid toon wat nie voorheen in Afrikaanse musiek gehoor is nie. In 'Hou my vas korporaal' word daar kritiek gelewer op militêre diensplig, en 'Snor City' het die hoofstad Pretoria gesatiriseer. Phillips se lirieke was nie noodwendig die eerste satiriese Afrikaanse liedjies nie, maar dit is wel een van die eerste kere wat die satire in "n populêre medium soos rock "n roll vervat is".

18 M. Andersson, Music in the Mix, p. 141.

19 P. Hopkins, Voëlvry, p. 79.

20 Phillips was known to like accents, particularly those of ordinary South Africans. He sang with what has been described as "his own honest South African accent" (K. Shoemaker, Review of Fresh Music: SA artists, 2001) and also deliberately used other South African accents. 
Most of these groups are writing songs that could be called 'political'. Or perhaps a better word would be 'topical' ... Barely days after the Silverton Siege, Corporal Punishment came out with a number called 'Down at the Bank', a song questioning who the real heroes were ... The Corporals don't claim to be anything but 'lazy middle-class whites' says Carl Raubenheimer, who pens most of their lyrics: 'We're not heavy liberals. We don't go specially and read the papers - you could probably take us as a barometer of public opinion. You know, there's just the fact that we say 'them'. That we talk of 'us' and 'them'. We're whities, and we might sing songs about 'them' because there's nothing to beat these people. It has got to that point where 'they' have nothing to lose but 'their' chains. So we feel we must give our audience that awareness. It's a very positive political stance. We don't offer any solutions. ${ }^{21}$

There is no evidence that Phillips thought of himself as a "lazy middle-class white;" 22 nor, as noted previously, that Raubenheimer wrote the majority of the band's lyrics. ${ }^{23}$ According to Andersson, when Corporal Punishment "first started playing around Johannesburg, they picked up a small staunch lefty following ${ }^{24}$ - until they came out with songs so fierce, like the one about Arrie Paulus, that the lefties couldn't be sure what they heard over the mike was ideologically sound or not. The use of the word kaffirs in this particular song lost the Corporals a few fans, even though the Corporals were satirizing a set of attitudes, not prescribing them."25

${ }^{21}$ M. Andersson, Music in the Mix, p. 141.

22 Nor is laziness suggested by the claim that "he worked at the songwriting, very hard, harder than rock'n'rollers are supposed to" (S. De Waal Cherry-faced Lurchers Liner Notes, s.d., www.freshmusic.co.za/cherry) (Accessed 2007-05-17.)

23 Grundlingh's view, albeit formulated much later, is far sounder and less self-serving than that of Raubenheimer: "Despite their on-stage appearance as down-at-heel dissolute punk rock artists, the musicians came from respectable middle class homes. A good sprinkling had tertiary education. What is striking, is that at least three members were the sons of ministers of religion and some of the others had a strict religious upbringing. Given the nature of the clerical profession, the parents were probably quite articulate and exposure to such a home environment might go some way in understanding the verbal acuity of the musicians and their facility for assembling novel lyrics. Moreover, their intimate knowledge of the inner workings of the Afrikaner social world in which 'dominees' played a prominent part, might have honed their senses for selecting suitable cultural elements for subversion. On another level, while bearing in mind that psychoanalytical interpretations of the wellsprings of behavior can be overdetermined, the dynamics of defiance against parental authority may indeed have featured in the make-up of some Voëlvry musicians" (A.Grundlingh, Rocking the boat, p. 487.)

24 The playwright Ryk Hattingh's remark, quoted in P. Hopkins, Voëlvry, p. 94, is appropriate to consider here: 'You were not left or right. You were in front.'

25 M. Andersson, Music in the Mix, p. 141. 
Few outside a loyal following took notice, claims Hopkins, they "were so removed from the mainstream," ${ }^{26}$ and the band split up at the end of 1980, although it mutated into Illegal Gathering. (Segerman notes: "Already clashing with the SABC and major label indifference, as well as with unwanted attention from the "security" establishment, Phillips then formed Illegal Gathering with David Ledbetter and Wayne Raath." ${ }^{27}$ ) Hopkins gives the following version in the words of Raubenheimer:

'One night, at about 3 a.m., I woke to the best riff I'd ever heard outside my window, and there was Mr Phillips,' remembers Raubenheimer. 'Together with David Ledbetter (bass), another Springs boy, and a drummer called Wayne Raath, we got Illegal Gathering together. In six weeks we rehearsed sixteen songs, played six or seven gigs, and recorded all the music. ${ }^{28}$

From then on, Phillips's musical life took off, in a variety of ways, beginning with his registration as a music student in 1981 at Rhodes University in Grahamstown. There he connected "with fellow Rhodes-student, Lee Edwards (bass). These two later in Johannesburg formed the basis of the Cherry Faced Lurchers, ${ }^{29}$ one of the most prominent and relevant rock bands of the " $80 \mathrm{~s}$ in SA." ${ }^{30}$ At the end of his first year at Rhodes University, and as James Phillips once more, ${ }^{31}$ he hitchhiked to Cape Town to spend the holidays with Raubenheimer.

\section{Identities, musical and otherwise}

Pavlicevic notes:

Identity is a complicated notion. It has to do with our sense of belonging to various groups - ranging from family, friends, regions, professions to broader groups such as gender or race. Identity also has to do with how we see ourselves within our various social groups, how we are seen by them, and what groups we are identified with in the public mind. The term 'identity' means different things in different places and at different times and, moreover, means more than one thing at a time: for instance, we think of our private and public identity and of our personal and collective identity. ${ }^{32}$

26 P. Hopkins, Voëlvry, p. 94.

27 S. Segerman, Fresh Music: SA artists. James Phillips, 2000. www.rock.co.za/files/james (Accessed 2007-05-17)

28 P. Hopkins, Voëlvry, p. 95.

29 Together with Mike Lurcher, later replaced by Richard Frost - see P. Hopkins, Voëlvry, p. 95.

30 S. Segerman, Fresh Music: SA artists. James Phillips, 2000. www.rock.co.za/files/james (Accessed 2007-05-17)

31 See below for a discussion of Phillips's varying identities while at Rhodes University for 2 years. 
In fact, descriptions of identities these days have even been extended to "the road as cultural identity" ${ }^{\prime 3}$ (and this would certainly have applied to Phillips's travels, and especially as part of the Voëlvry tour) and "textual identity" ${ }^{34}$, which can definitely be applied to Phillips as lyricist. DeNora goes so far as to claim: "Music is not simply used to express some internal emotional state...it is a resource for the identification of knowing who you are." ${ }^{35}$ So who was Phillips, musically and otherwise?

According to Phillips's family, his identity always remained that of an 'English' South African, and additionally he knew that he had earned a BMus degree, specialising in Composition, making him far more musically literate than the average pop musician. ${ }^{36}$ Yet much available literature on this seminal musician of turbulent 1980s/90s South Africa fails to mention Phillips's formal musical studies, and situates him as more of an Afrikaans musician, alongside the likes of Koos Kombuis and Johannes Kerkorrel, although sometimes mentioning his English background. ${ }^{37}$ Phillips's father and mother agree on his desire to assist young Afrikaners in the development of a positive identity, also in terms of Afrikaans music, without ever denying or abandoning his own middle-class English-speaking roots.

Grundlingh states that "Underlying their position was also an attempt to make Afrikaans part of a wider world through rock and roll." 38 "Their" refers to "Voëlvry", but it is interesting that Grundlingh continues with specific reference to Englishspeaker Phillips: “As Bernoldus Niemand explained, 'The Afrikaner was the polecat of the world, part of nothing, rejected. I tried to bring him in, make him feel part of something' (this quotation from Niemand comes from an article in Die Burger, 199401-04, "Oupa Phillips se klong mik kop toe”). Grundlingh goes on immediately: "Similar concerns also fed into their rejection of the term 'alternative Afrikaners' which the

32 M. Pavlicevic, Groups in Music: Strategies from Music Therapy (London, 2003), p. 193.

33 Title of May 2007 photographic exhibition at Sheraton Hotel at Frankfurt airport.

34 Staff writer D. Rogers, Search for tomorrow, Stanford magazine, May-June 2007, p. 34.

35 T. DeNora, Music in everyday life (Cambridge, 2000), p. 57.

36 L. Hagen, Kulturele identiteit, p. 22) notes: "Phillips het sy B.Mus in 1986 aan die Universiteit van die Witwatersrand voltooi. Hierdie formele musiekopleiding het volgens Savage (1989:10) bygedra tot sy musikale afronding wat teenoor Kerkorrel en Letoit se entoesiastiese, maar onafgewerkte repertoire uitgestaan het. 'Niemand/Phillips is the musicologist of the Voëlvryers and his compositions sparkle with musical ingenuity." Phillips's family confirm that he himself spoke little about his achievements in this regard, but some of his close friends took pride in their mention.

37 Grundlingh is the only author I could find who actually refers to Phillips as specifically having "something of a bilingual background" (A. Grundlingh, Rocking the boat, p. 486), although of course this type of background is so common in South Africa as scarcely to warrant noting.

38 A.Grundlingh, Rocking the boat, p. 495. 
media bestowed upon them." ${ }^{.39}$ In Kerkorrel, Pretorius chooses to quote Dagga-Dirk Uys as saying:

Wat baie mense vergeet, wat my groot missie was, was om Afrikaanse rockmusiek te vestig. Om dit 'n realiteit te maak sodat daar Afrikaanse musiek vir jong mense is. Ons het ook gemeen dis 'n manier van inligting na die jeug toe deur te kry. Dit was 'n bevrydingsding en het derduisende uit die bestaande dogma bevry. Dis hartseer dat mense van die musiek vergeet as hulle van die beweging praat. Ons het weer 'n trots geskep in Afrikaanse musiek. Dit was die begin van Afrikaanse rock. Vandag is dit alledaags. ${ }^{40}$

These words could equally have been attributed to Phillips.

Delport contends that the identity crisis of the Afrikaner is not only instigated by external societal changes. ${ }^{41}$ This author concurs with Delport's belief that it is essentially rooted in the tension caused by clashes between identification and disidentification. ${ }^{42}$ To what extent did Phillips also feel himself part of this identification/ dis-identification tension? Delport continues:

As a result, our ${ }^{43}$ ideas of what we formerly regarded as important and valuable are now muddled and disorganised. We tend to question the validity and authenticity of The Self, which 'we had imperceptibly acquired from birthand even before, in our racial inheritance.' ${ }^{44}$ We also question our former notion of The Good. Van Wyk's perplexity about our 'unquestioning acceptance of the virtues and indeed the inevitability of apartheid,' ${ }^{45}$ and Krog's inner wrestling to come to terms with 'the fact that all the words used to humiliate, all the orders given to kill, belonged to the language of my heart' ${ }^{46}$ represent many Afrikaners' remorse about their ignorance and indifference regarding the predicaments of blacks.

39 A.Grundlingh, Rocking the boat, p. 495.

40 W. Pretorius, Kerkorrel (Cape Town, 2004), p.34.

41 A. Delport, Canto ergo sum: I sing, therefore I am, Muziki 3(1), 2006, pp. 5-15.

42 See Epstein, Hewitt, Leonard, Mauthner \& Watkins, Avoiding the issue: homophobia, school policies and identities in secondary schools, in C. Vincent (ed), Social justice, education and identity (London, 2003), p. 121.

43 Note: the "our" and "we" referred to here are Afrikaners, of whom Delport is one.

44 A. Van Wyk, The Birth of a new Afrikaner (Cape Town, 1991), p. 9.

45 A. Van Wyk, The Birth of a new Afrikaner, p. 9.

46 A. Krog, Country of my skull (Johannesburg, 1999), p. 361. 
Even if Phillips did not regard himself as an Afrikaner, the above certainly applied to him, and especially after his period of study in Grahamstown, described below. Pretorius quotes the Afrikaans actor and director Marthinus Basson, stating, and including Phillips in this description: "Die Engelse het oor ons gerave, want hulle het die eerste keer kennis geneem van 'n nuwe Afrikaner wat nie by hulle stereotipe ingepas het nie. Vir hulle was dit heeltemal vreemd om 'n groep moderne Afrikaners te sien wat nie in hulle spotpatroon ingepas het nie." ${ }^{47}$

When Hopkins wrote about "the Gereformeerde Blues Band ... a vision for a liberated language - Afrikaans as cool, as opposed to being the tongue of the oppressor. In this they dived headlong into the resurfacing debate around Afrikaner identity and the place of the volk in the country," 48 this was also applicable to Phillips, although he was not a member of this particular band. Equally the following applied to him: "We protested against the system without giving up being Afrikaners. We didn't discard or write off the ossewa; we gave it a facelift and fitted it with a V6 engine. It was the one attack the Bothas had not anticipated." ${ }^{49}$ Including Bernoldus Niemand en die Swart Gevaar, Johannes Kerkorrel was another rocker who wrote: "It was a collective effort to entrench freedom of speech for Afrikaans youth. We were part of a greater protest movement. ${ }^{\text {50 }}$ Hopkins writes about Johannes Kerkorrel meeting:

Dutch singer Stef Bos in a coffee shop in Antwerpen, and in 1993 invited him to South Africa to record a Dutch-Afrikaans compilation titled Awuwa/Zij wil dansen with Thandi Klaasen ... 'a marriage between the Afrikaner, its past (Bos) and its future (Klaasen),' wrote Johan Pieterse in Rapport. In that sentence, Pieterse captured the dilemma of Kerkorrel - the frustration of trying to come to terms with himself within the Afrikaner identity. Was he a White African? A displaced European? Or a South African who happened to speak Afrikaans? ${ }^{51}$

Phillips appears not to have had the same feelings of angst described above, and yet to have joined together with and wholeheartedly supported Johannes Kerkorrel and others in articulating these problems, and leading Afrikaans youth in a search for solutions.

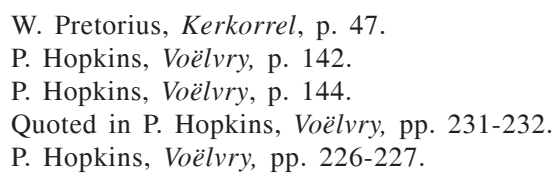


At Rhodes University, in the post-Corporal Punishment days and before his involvement with the Voëlvryers, Phillips was continuously searching for his identity. As the composer Shaun Naidoo noted: "I think it was difficult for him to be there. The whole setting was a far cry from Springs, his spiritual home." ${ }_{52}$ Although he never lived in Springs again, it arguably remained Phillips's 'spiritual home', life-long. Hopkins highlights in his book ${ }^{53}$ an apparent quotation from Phil Millan, writing in the Star newspaper: "Bernoldus is the urban East Rand 'Dutchman' - the most South African of all Afrikaners." However, a full reference for this quotation is not given.

\section{English Phillips/James the Boptist/Bartholomew Biased:Afrikaans Niemand}

Grundlingh refers to Phillips "assum(ing) the stage name, Bernoldus Niemand (Mr Nobody as he liked to style himself). ${ }^{, 54}$ Lloyd Ross of Shifty Records explained it thus: " "Bernoldus was a flirtation for James. In the early 1980s, he was trying to define himself personally and politically and experimented a lot with music and his own identity. But Bernoldus didn't work for him, and he'd moved on by the time Wie is Bernoldus Niemand? was released. ${ }^{55}$ In fact, he was always a bit embarrassed by it." ${ }^{56}$

"Flirtation" is one term that can be used for Phillips's various noms de plume: others are "alias," 57 "alter ego" or "persona" or "personae", as claimed by Shoemaker:58 "Phillips adopted personae, too. That is, he put on various faces much as the Beatles sometimes pretended to be made-up rockers ... Phillips's Bernoldus Niemand personality sounds interesting, like a voice from no one, or from the people. Sometimes Phillips even sounds like Randy Newman, then he's back to solidly James Phillips." 59

In writing about "the importance and iconic status of the Alternative Afrikaans Music Movement, or Voëlvry Movement as it is now more commonly known, it is important to pinpoint where and when it began, and who the initial driving force

\footnotetext{
P. Hopkins, Voëlvry, p. 95.

P. Hopkins, Voëlvry, p. 98.

A.Grundlingh, Rocking the boat, p. 486.

In 1984.

P. Hopkins, Voëlvry, p. 91.

L. Hagen, Kulturele identiteit, p. 20.

K. Shoemaker, Review of Fresh Music: SA artists, 2001. www.rock.co.za/files/jp made (Accessed 2007-05-17)

59 L. Hagen, Kulturele identiteit, p.21) gives a much more serious explanation, referring to a Donaldson article, when she writes "Die skuilnaam, Bernoldus Niemand, was ... die gevolg van Phillips se vrees dat die militêre polisie hom vir verdere militêre kampe sou opspoor." Although his family (in personal 2007 interviews and correspondence) do not deny this possibility, they note that he told them that Bernoldus was "no-man or everyman".
} 
behind it was," writes Hopkins. ${ }^{60}$ He continues: "a sizeable body is convinced it began with the appearance of Bernoldus Niemand, the cowboy-clad satirical Afrikaans alter ego of English-speaking Springs rocker James Phillips. This is also way off the mark, because his influence was of the coincidental variety - and never that strong". This last point is a different issue, and one which can be hotly contested, on the basis of the testimony of many other rock musicians of the time. ${ }^{61}$ And it should also be noted that, despite never having met Phillips himself, Hopkins makes such strong statements about the man without having taken the trouble to interview many people such as close friends or family, who have valuable additional insights to offer and are freely available to give these.

It is nevertheless worth quoting at length the following extract from Hopkins's book: ${ }^{62}$

At the same time that Phillips was forming the Cherry Faced Lurchers, he was working on another persona - Bernoldus Niemand. In 1983, Shifty released 'Hou my vas korporaal' as a single. It was a flop, and when he complained about this to Shifty, they handed him a pile of records to see if he could do any better... 'A few days later, he announced, amazingly, that he'd gotten rid of the lot,' wrote Andrew Donaldson in the Sunday Times. 'Within a matter of weeks, however, a somewhat different story emerged when a concerned clerk from CNA's Johannesburg head office called up the record company, inquiring about the piles of Bernoldus singles that had mysteriously appeared in the racks of their music department; they certainly hadn't ordered them. In a sort of reverse-shoplifting spree, Phillips had smuggled them in himself. He would not listen to explanations as to why this wasn't exactly the way record companies, even small independent labels like Shifty, did business. There was, for example, the matter of accounting for stock, the logging of receipts and all sorts of bookish stuff regarding monies owed. Phillips's simple response was that, well, now at least people could buy Hou my vas korporaal because it was in the shops. And not just some grubby alternative music outlet in Rockey Street, Yeoville, but an established traditional newsagent chain -

\footnotetext{
60 P. Hopkins, Voëlvry, p. 91.

${ }_{61}$ For example Hagen notes (Kulturele identiteit, p. 34): "Mediawaarnemers het verskil oor watter kunstenaar die drakrag van die Voëlvry-toer was ... Bernoldus Niemand en Die Swart Gevaar was volgens Dickson (verwys na P. Dickson, Blues 'volk' band sets PE dancing, Weekend Post 14, 1989-05-20, p. 14) musikaal die beste afgerond. Niemand "has come to set the pace and style of the new music."

62 P. Hopkins, Voëlvry, pp. 97-98.
} 
like the CNA ... Undeterred, Shifty Records released 'Wie is Bernoldus Niemand?' 63 'There is very little available information on South Africa's latest phenomenon, Bernoldus Niemand,' read the blurb on the back cover of the album. 'There have been a few reports in the press, but precious little about the man. He is extremely difficult to get hold of, but we tracked down his sister, Marie Niemand (16), and she had the following to say about her mysterious brother: "I really don't know why Bernoldus still stays in Springs, he says it gives him perspiration or something. He always looked after me, especially when I was little. Every Sunday evening he used to take me to Third Street where the ous park their tjors and bikes after spending the whole day cleaning them. I used to earn bucks polishing hubcaps and things so's I could buy Texans for 'Noldus. Then when I was older he used to tell Ma and Pa that he was taking me to make coffee at band practice, but he would let me go to the disco with Cheryl and Suzette instead. He was always my hero. All my school chommies loved him, but sometimes he used to go all quiet you know, like he had a mood. He used to call it a dinkbreek [think break], then he'd go and write one of his chunes. I skeem sometimes, you know, that he's going to be a big star and live in Hollywood or Sandton and the only time we'll see him is when we go to the CNA and see his poster on the wall." ${ }_{64}$

63 The album is described by J. Pieterse (Rock op Afrikaans, De Kat 16(3), 1988, p. 11) as the first "alternatiewe langspeelplaat", which had a profound impact on later so-called Alternative Afrikaans music - in the words of S. De Waal (Rocking rebels discover R'R, Weekly Mail, 23 Feb-1 Mar 1989, p. 28) "Many consider Bernoldus Niemand's album, Wie is Bernoldus Niemand? to have started the Afrikaans 'new wave' which has climaxed in the Voëlvry tour. It was the first record of its kind, and it set the tone: observant, satirical (sometimes gently so, sometimes more bitingly), and couched in the rebellious language of rock " $\mathrm{n}$ roll".

There was little chance of such publicity for Wie is Bernoldus Niemand? The SABC banned most of its tracks, and so it could not enjoy airplay, despite critics raving about it. L. Hagen (Kulturele identiteit, p. 21) writes the following: "Die SAUK het "n uitsaaiverbod op Wie is Bernoldus Niemand? geplaas, maar volgens Donaldson (A. Donaldson, The last days of James Phillips, Style, October 1995, p. 69) was die invloed van die album reeds op die latere Alternatiewe Afrikaanse Musiek groot. "But that [die uitsaaiverbod-LH] didn't stop it from influencing a whole generation of rebel Afrikaners, like Koos Kombuis and Johannes Kerkorrel, who later went on to spearhead the Voëlvry movement." Die uitsaaiverbod op Wie is Bernoldus Niemand? ... deur die SAUK kan gesien word as die sentrum wat nie die periferie wil erken of toelaat dat die periferie bestaan nie. Die monolitiese konstruksie van die Afrikanerkultuur word bedreig deur die alternatiewe wat geskep word deur die periferie. Die uitsaaiverbod deur die SAUK, wat in die sentrum van die Afrikanerkultuur gestaan het, dui op die hewige negatiewe reaksie van die sentrum teenoor die periferie." For a lengthy review of the album see Phil Millan in the Star, quoted in Hopkins (P. Hopkins, Voëlvry, p. 98). In fact, in the same article Millan described the concept underlying Bernoldus Niemand as "simple and elegant" - two adjectives which one is hard-pressed to find applicable to James Phillips. 
When Phillips unveiled his "slaughterer of Afrikaans sacred cows" alter ego, Bernoldus Niemand, the sneering and mysterious "gunman" image on the album cover further established him as a leading influence of the "Voëlvry" alternative, Afrikaans rock renaissance alongside Koos Kombuis, Valiant Swart, Willem Möller and Johannes Kerkorrel. ${ }^{65}$ Drewett is the only author found who makes the claim that "As Bernoldus Niemand, Phillips dons a caricature voice in many of the songs. Here ... the voice (ostensibly through the accent) becomes ... a "vocal costume." ${ }^{66}$ Writing about Johannes Kerkorrel, Fred de Vries in the Mail \& Guardian noted: 'It is the product of a man who has many local scores to settle - that's when he uses Afrikaans." ${ }^{67}$ The same may equally well have been said of Phillips.

Pseudonyms/noms de plume have been and still are widespread among (alternative) Afrikaans musicians, with some of them adopting several different ones, over periods of years, and even alternating between them. ${ }^{68}$ While at Rhodes University in Grahamstown, Phillips appears to have had very brief flirtations with two English aliases. The situations are described as follows:

'I was a first year student and had been in Grahamstown for a day when this very strange character walks up, 'says composer Shaun Naidoo. 'He's wearing an overcoat that's been patched in various different places; has a guitar, which he's playing; his head is almost completely shaved; and on his jacket is a home-made badge that reads: "You've got to be crazy to look at me this way." He walks up to me and asks if this is the music department. I said it was, and he then introduced himself as Bartholomew Biased. So for three days I called him Bartholomew. ${ }^{69}$

Grahamstown dramatically exposed Phillips to the plight of black South Africans. ${ }^{70}$ In much of South Africa, townships are out of sight, out of mind, so that the effects of

65 S. Segerman, Fresh Music: SA artists. James Phillips, 2000. www.rock.co.za/files/james (Accessed 2007-05-17)

66 M. Drewett, Satirical opposition in popular music within Apartheid and Post-Apartheid South Africa, Society in Transition 33(1), 2002, p. 91.

67 P. Hopkins, Voëlvry, p. 228.

68 It is interesting, though, the number of times such musicians have been angered by what they have seen as satirization of themselves - witness Johannes Kerkorrel's fury at what he saw as his inclusion in Koos Prinsloo's openly gay Slagplaas, and Phillips's apparently mistaking the character James Sideburns in Andre Letoit/Koos Kombuis's first English novel, Paradise Redecorated, as a satire of himself.

69 P. Hopkins, Voëlvry, p. 94.

70 Not much is written about Phillips's views on Black-White relations in South Africa, although his mother recalls his deep upset about the fact that at that time he could not even have a cup of tea in a restaurant with his Indian friend Shaun Naidoo, for example. One passage from 
apartheid are hidden from white residents. But the township is in full view above Grahmstown, and what Phillips saw affected him deeply. Soon he joined the local Presbyterian $^{71}$ church and became involved in their musical activities. "Adjusting Christianity to fit his lifestyle, he became James the Boptist for a short while. 'He walked around campus in a long jacket wielding an old, battered Spanish guitar; a desperate stumbling troubadour for Jesus,' wrote fellow student Chris du Plessis." 72

\title{
The Voëlvry Movement
}

\author{
With Voëlvry, "Afrikaans suddenly became sexy. Voëlvry was the Boere-Woodstock."73 \\ Elsewhere the descriptions "Boere Beatlemania" and "apoplexy within the Afrikaner \\ establishment" are offered by Hopkins,${ }^{74}$ and all of this very much included Phillips. \\ Again Max du Preez writes:
}

Kerkorrel does perhaps provide the insight that he was largely unaware of racial differences between fellow human beings, so that the racial issues in South African society at the time troubled him less than general societal and moral issues. The well-known Black musician, Vusi Mahlasela, is quoted as saying "Hy [i.e. Johannes Kerkorrel] en ander kunstenaars soos James Phillips (Bernoldus Niemand) het saam in 'n vervalle huis in Goudrifstad tussen Johannesburg en Soweto gewoon. Ek het in die agterplaas van die huis in die buitekamer gebly... Hy en James Phillips was die grotes van daardie tyd. Hulle was so gemaklik en het geglo in wat hulle doen. Een keer nadat hulle weggetrek het, het ek hulle in Rocky-straat in Yeoville raakgeloop. Hoezit bra, het hulle gesê. James, hy was 'n anderste man, het dadelik twee biere uit sy jas gehaal en ons het dit daar saam op die sypaadjie gedrink, gelag en gesels. Die mense wat om ons geloop het, het ons vreemd aangekyk want hulle was nie gewoond dat wit en swart mense so saam kuier nie. Jy mag ook nie op straat gedrink het nie, maar James-hulle het nie omgegee wat mense dink nie" (W. Pretorius, Kerkorrel, p. 52). Dawn Joseph (2007 email correspondence), an Indian fellow-student of Phillips's at Wits writes: "James always spoke his mind whether it was about the weather, the politics at the time or just the music dept at wits - he also loved hanging out in senate house where he would sit on the floor with his coffee and ciggie - dressed casually - most times with his guitar... totally against the system of good old apartheid - James was one of few that did not 'mind' so to speak he would just say "F" the rest ..." Carl van Wyk (email of 2007-08-01) recalls the following: "James being consistently late for composition lessons, always dressed in that old, smoke-permeated coat, bare-feet, and trying to direct the focus of the class to the predicament on the streets, the developing chaos in the country - he would ask, "do you (all of us in the class, trying to concentrate on 20th century Western composition techniques) KNOW what is going on?" I would have my job cut out trying to redirect the class to the purpose of the class, writing music. In retrospect I should have given James more time to stir - the other students were far too complacent."

71 Not a spiritualist church, according to his family (Phillips interviews, 2007), and as claimed by Hopkins.

72 P. Hopkins, Voëlvry, p. 95.

73 Foreword by Max du Preez to P. Hopkins, Voëlvry (Cape Town, 2006).

74

P. Hopkins, Voëlvry, p. 19. 
It was a significant movement in every social, political, cultural and musical sense of the word. Five months before the Voëlvry tour, I had launched an irreverent, anti-establishment Afrikaans weekly newpaper called Vrye Weekblad. We had no respect for authority, and we saw it as our duty to make fun of the Fathers of the Volk. We had a general fuck-you attitude, and didn't believe the 1980s was a time for subtlety and good manners. We were labeled 'alternative Afrikaners'...The Voëlvry movement had its first stirrings during exactly the same time. Johannes Kerkorrel, Koos Kombuis, Bernoldus Niemand, Dagga-Dirk Uys and the other Voëlvryers had similar instincts and attitudes, the same irreverence, the same sense of being agents of change. And yet the two movements developed independently - there was no contact between us and them until both projects had built up substantial steam. Both groups sensed that the time was right for a hurricane of change to blow through the arrogant, narrow-minded, insular, authoritarian and racist world of Afrikaner nationalism. Die Totale Aanslag se moer. That was why Vrye Weekblad became a sponsor of the Voëlvry tour, with Lloyd Ross's Shifty Records. (Lloyd's contribution to the new Afrikaans music movement can hardly be overstated, despite the fact that he was, like James Phillips, aka Bernoldus Niemand, an Engelsman. $)^{75}$

For further discussion of Ross's role, see the section The Role of Lloyd Ross and Shifty Records below.

On the following page of his Foreword ${ }^{76}$ Du Preez claims: "Voëlvry ... boosted the Afrikaans language like few events before it, and that a few years before Afrikaans lost its privileged official status. And it proved that Boere can rock in their taal, after all." “... how can Hermann Giliomee write a 700-page book, call it The Afrikaners Biography of a People, and not even mention the existence of the Voëlvry movement or its impact? ... Voëlvry was the beginning of a major explosion in Afrikaans music ... the most under-documented social movement of the last few decades." 77

Hopkins also writes about what he describes as "a minor revolution in mainstream Afrikaans music" $"$ - Pretorius describes it as strongly as "Kerkorrel en

\footnotetext{
75 P. Hopkins, Voëlvry, pp. 6-7.

76 P. Hopkins, Voëlvry, p. 8.

77 Another question which can equally well be asked is how in 1989 Christopher Ballantine could write an article in the well-known journal Popular Music, entitled 'A brief history of South African popular music' and not even mention any Afrikaans music/bands by name, let alone Phillips by name.

78 P. Hopkins, Voëlvry, p. 56.
} 
die kunstenaars van die Voëlvry-era het vir 'n kulturele revolusie in Suid-Afrika gesorg wat die lewens van 'n generasie verander het." 79

While Botha was taking power [1977/78] ... By then the Broederbond with their lekkerliedjies had lost most of the younger generation, who would not be caught dead listening to Afrikaans music ... Until then it was thought that Afrikaans was too guttural to translate into rock ' $n$ roll, but that all changed with Anton Goosen's Boy van die Suburbs ... Led by Goosen and Laurika Rauch, the new sound came to be known ... most popularly as Musiek-enLiriek (Music-and-Lyric), after the Afrikaans TV music series that was then airing on $S A B C \ldots$ What it did was replace the banal lekkerlied with dynamic rhythm and beautiful lyrics that challenged the listener, but were devoid of social or political comment. 'It was so Eurocentric and elite,' sneered Johannes Kerkorrel. 'It was all so subtle, so literary, so fashionable. Good taste was so important.' 'The reason Goosen was the target of much later rage is that he thought he could change the system from within - toeing the line because he needed to make a living,' comments journalist Max du Preez. 'But it must never be forgotten that he paved the way for the Voëlvry movement by demonstrating that rock could be played in Afrikaans and that there was an audience for it. ${ }^{80}$

Any discerning reader can easily conjure up an image of Phillips in relation to all of the above.

Hopkins is of the opinion ${ }^{81}$ that "generally the establishment had not yet awoken to this new challenge. That would come after 25 March 1988, with Die Eerste Alternatiewe Afrikaans Rock Konsert ${ }^{82}$ - the event where Bernoldus Niemand appeared live for the first time ${ }^{83}$ and Alternative Afrikaans Music became a movement". It is notable that this was apparently the first "event where Bernoldus Niemand appeared live", and this is clearly a demonstration of the man's level of privacy (referred to in the Abstract to this article), despite being a rock musician.

\footnotetext{
79 W. Pretorius, Kerkorrel, p. 10.

80 P. Hopkins, Voëlvry, pp. 56-57.

81 P. Hopkins, Voëlvry, p. 151.

82 Note: in Johannesburg.

83 In describing this, Pretorius (W. Pretorius, Kerkorrel, p. 12) writes: “'n Groep jong Afrikaanse kunstenaars stig 'n beweging en organiseer wat later bekend sou staan as Die Eerste Alternatiewe Afrikaanse Rockkonsert in Johannesburg... Die toer... sluit groot Afrikaanse rockrebelle soos James Phillips (Bernoldus Niemand) in ..."
} 


\section{The Voëlvry Tour}

According to Hopkins, ${ }^{84}$ "Voëlvry ... started out on 4 April 1989 at the dingy packed Club Countdown in Bree Street in downtown Johannesburg. First up was the subversive poet and folk singer André Letoit, who was followed by Bernoldus Niemand en Die Swart Gevaar." ${ }^{55}$ "The Voëlvry tour's ossewa was seen off by about 600 people ... at the start of a two-month jive into the cultural wilderness." ${ }^{86}$ Hopkins also refers elsewhere to this tour (see, for example, the inside cover of his book), and in all instances, it is notable that Phillips is mentioned by name, even when others are left out of the list.

Did the tour precede the movement, the movement the tour, or were both intertwined, and to what an extent? Perhaps Phillips himself captured the essence (and especially as the political developments in the country are viewed with hindsight): “'I think Voëlvry helped bring about change,' said James Phillips. 'It was the kind of encouragement reformers needed, the knowledge that the laaities [boys] were behind them. The support was incredible - from Johannesburg to Cape Town to Bloemfontein. Everyone was behind us - black, white, brown - everyone." "\$87

\section{The Role of Lloyd Ross and Shifty Records}

Marketing and distribution of what is widely seen as subversive music is always problematic - and especially so in the type of police state that South Africa was in the 1970s/80s. Andersson notes: “To start with CCP was the only company at all interested in new wave, probably because it was distributing Stiff records. It started promoting unsigned bands like ... Corporal Punishment." ${ }^{88}$ She makes no mention in the book of either Lloyd Ross personally or Shifty Records - no doubt because her book was simply published too early on in developments. ${ }^{89}$ Yet Hopkins gives the following credit:

84 P. Hopkins, Voëlvry, p. 14.

85 Hagen (L. Hagen, Kulturele identiteit, p. 21) notes: "Die groep Die Swart Gevaar het saam met Phillips die Voëlvry-toer meegemaak. Die naam Die Swart Gevaar is 'n verwysing na die politieke mobilisering van swart groepe teen die Apartheidsregering. Die gebruik van ' $n$ gelade politieke term as groepnaam binne die konteks van die Voëlvry-toer is " $\mathrm{n}$ aanduiding van die verset teen die status quo wat die groep voorgestaan het."

86 P. Hopkins, Voëlvry, p. 174.

87 P. Hopkins, Voëlvry, p. 204.

88 M. Andersson, Music in the Mix, pp. 138-139.

89 See the date of 1984 at the end of the following paragraph. 
It is thanks to the passion of Ross that true South African music and the angry voices of the 1980s were documented for posterity. However, he will not primarily be remembered for this, but rather for the revolution he facilitated in Afrikaans music - an interest which began when he released 'Wie is Bernoldus Niemand?' in 1984. ${ }^{90}$

Shifty Records had already released The Voice of Nooit, sent to them by Phillips, ${ }^{91}$ well before the single of 'Hou my vas korporaal' in 1983. In 1990 Shifty released songs recorded between 1985 and 1989 by the Cherry Faced Lurchers on The Otherwhite Album:

'A massive 20 tracks on this one, including the Live at Jameson's release of yore and new material long left languishing in a vault in Sweden,'stated a review in the Star. 'Side One, consisting of the new material, was recorded "live" in the studio. It's all firmly garage-band mould, but then that's what they always were, given the situation in this country for "white" bands". The music on "Detainees" is great stuff, simple, sparse, lots of spaces. And the lyrics by rights should have become staple fare by now. "Heavy Ous" is a blerry good song too: "From childhood you were taught to hate/The socalled enemies of the state." "The Branch", a slowie, is a diatribe about the special branch, while "War Song" is a slice of brilliance, one of the best antiwar songs around. There's so much talent here; an invaluable part of Lurchers' history.' ... When 'The Otherwhite Album' was released, Phillips and the Lurchers were putting together 'Sunny Skies', which was released in 1994 the year Phillips stood in South Africa's first democratic elections as a candidate for the highly eccentric Soccer Party ... 'Sunny Skies will be remembered as James's most accomplished and most sophisticated album,' comments Moller. 'Lyrically his new songs reflected his hopes and fears for a new South Africa, and the dark and angry words of the 80s were being replaced by songs of optimism like "Why can't we (love one another)?" and "(I want the world to) start again". Although highly praised by critics, a distribution deal by major record label BMG failed to do the album justice. Once again, the industry failed to notice the talent lurking under their noses.' ... Journalist Andrew Donaldson, a friend of Phillips's, wrote an article blaming BMG's poor distribution for causing the album to sink 'without a trace'. Threatening

\footnotetext{
90 P. Hopkins, Voëlvry, p. 89.

91 P. Hopkins, Voëlvry, p. 95.

92 P. Hopkins, Voëlvry, p. 214.
} 
to sue, an executive at the music company responded: 'James was a fuck-up. He did nothing to help us with the record. Have you ever tried to get him to do a morning TV interview? He refused. Simply refused. And that's the story of this fucking record! 92

\section{Voëlvry the end of Bernoldus Niemand?}

The question posed by this heading is suggested by Hopkins: ${ }^{93}$

'Post-Voëlvry he lived a life not far from that of a hobo,' says friend and musician Roger Lucey. 'He had a place to live, but was forever scratching together pennies. He lived a cruel life and, as it went on, it got crueler. He would mount peaks and pinnacles, but would always crash off the other side. That's the story of South African music.' 'James continued to have an anarchic attitude,' adds Mike Lurcher ... 'The thing that got him was not poverty, but the lack of recognition.' 94

On the other hand the heading can merely be seen as referring to the fact that " $\mathrm{Na}$ afloop van die Voëlvry-toer het Phillips afgesien van die skuilnaam Bernoldus Niemand"95.

In 1990 Phillips worked as subeditor at City Press, teaching music theory and piano at the Alexandra Arts Centre. The following year he appeared at the National Arts Festival in Grahamstown, after which he and Letoit/Koos Kombuis left for Belgium to perform at the Dranouter Folk Festival. Once back, Phillips assembled a new band, The Lurchers, which included Willem Moller.

93 P. Hopkins, Voëlvry, p. 212.

94 Carl Raubenheimer also refers to "the saddest thing is that he'd received no recognition," and especially in comparison with a band like the Springbok Nude Girls, with whom Phillips was apparently not impressed (P. Hopkins, Voëlvry, p. 215) and Hopkins himself (P. Hopkins, Voëlvry, p. 91) refers to the recognition which Phillips "craved and never received", claiming that "For him it remained a cruel irony until his tragic death that the only significant audience he ever attracted was from a joke", with the "joke" referring to the adoption of the persona Bernoldus Niemand. Hopkins (P. Hopkins, Voëlvry, p. 212) also claims to quote from Letoit, using slightly different words from those he used on p. 91 of his book : "James wanted a normal career in a normal society. He knew he was talented. But the only thing he ever got noticed for was Bernoldus Niemand... He was not Bernoldus, it was not who he was, and it was a great problem that he never got the respect he deserved."

95 L. Hagen, Kulturele identiteit, p. 22, referring in turn to M. Markovitz, On the roll, The Sunday Star, 1989-07-30, p. 20. 
'I first worked with James on the Voëlvry tour when I played with his backing band, Die Swart Gevaar,' said Moller. 'Having been a Lurchers fan ever since Live at Jameson's, I immediately said yes when he asked me to join a new Lurchers line-up in early '92. James seemed to be heading in a fresh direction musically, using more complex song structures, bigger arrangements and horn sections where possible. In contrast to the earlier material, the new songs showed a strong jazz influence.' 96

Andrew Donaldson wrote in his obituary for Phillips in Style magazine after his death in July from complications following a car accident near the 1995 National Arts Festival:

During the early hours of Tuesday, July 11, James had been driving on a dirt road to Grahamstown from Riebeeck East, where he had been visiting a friend on a farm. He later said he had taken a wrong turn on that route and, turning around, had become angry with himselffor wasting time as he had wanted to catch up on some sleep. James had two performances that day - one with Theatresports, where he banged out impromptu tunes for actors' improvised sketches, and his own solo show - plus he had to punch in a few hours with Ecna, the Eastern Cape News Agency, who had employed him as a freelance journalist for the festival's duration. ${ }^{97}$

Rather than reaching an end, musically or otherwise (and as Moller noted above, that he was in "a fresh direction musically"), Phillips is also described by Segerman, ${ }^{98}$ post-Voëlvry, as "moving towards a more hopeful, piano-based, jazzy sound. In late ' 93 ... produced his most accomplished and (sadly) last, full original album, the light, fresh and gorgeous, 'Sunny Skies." Segerman attributes this to "Ever the prophet, Phillips then moved away from the anger and cynicism of his earlier material and, sensing the oncoming cosmic political change ...", but there is no clear evidence of this prophetic, political view, and the development can purely be regarded as continuing musical maturity of a trained musician. In fact, Segerman writes later in his article, about the posthumously released album 'Soul Ou', "The songs range across the many styles that Phillips handled with such ease including blues, folk, jazz and rock. ${ }^{99}$ They are all shot through with his renowned humour, irony and cynicism.

96 P. Hopkins, Voëlvry, p. 214.

97 P. Hopkins, Voëlvry, pp. 214-215.

98 S. Segerman, Fresh Music: SA artists. James Phillips, 2000. www.rock.co.za/files/james (Accessed 2007-05-17).

99 Segerman does not mention classical music at all, whereas Phillips's family note this particularly, right from the time of his Composition studies, when, according to his brother, he even wrote piano pieces using the 12 tone technique, through to the work he was doing 
They reflect the mixture of relief, concern and overall optimism of the new democracy in which he found himself. The old targets were gone and Phillips began to look inward for his subject matter." This appears in itself to contradict a prophetic, political view of developments in Phillips's music, suggesting merely that the dispensation had changed and, possibly also as a result of personal development, Phillips appropriately began to look elsewhere for his inspiration.

\section{James as artist}

Removed from the mainstream (and especially in Apartheid South Africa) Phillips may have been, in one sense, but he and his bands did draw "educated, cult audiences who tended to support them for their political stance as much as for their music"100. Several writers refer not only to cult audiences, but to the cult status of some of Phillips's songs. ${ }^{101}$

Called by Segerman a "great artist," 102 Shaun de Waal described Phillips as positively as "the key rock'n' roll intelligence of the Eighties." ${ }^{103}$ In the same liner notes he wrote: "he was as appreciative of Shostakovich as he was of the Stones. He was always a rake among scholars and a scholar among rakes." Quoting Raubenheimer (again writing about Phillips in a positive way, yet with the typical twist in the tail), Segerman presents the original "East Rand cowboy, singer, songwriter, musician, guitarist, composer, cultural icon, voice and conscience to generations of apartheidera (and after) white South Africans." Hopkins agrees ${ }^{104}$ that "Phillips deserves recognition as South Africa's greatest pioneering rocker," but then appears metaphorically almost to pull the rug from under his own statement by adding "But this story is concerned with Voëlvry, not with correcting the history of South African rock. As such, Phillips is a bit player, even if his songs 'Hou my vas korporaal,' 'My broken heart' and 'Snor City' became mini-anthems of the rebellion. The truth is that

right at the end of his life with the famous William Kentridge, co-composing music for Faustus in Africa.

100 M. Drewett, Satirical opposition in popular music..., p. 89.

101 W. Pretorius, Kerkorrel, p. 36 - “'Snor City” van Bernoldus Niemand en sy soeke na net een ongeskeerde bolip in Pretoria het later kultusstatus verwerf... p. 43 - Verset het ook in musiek tot uiting gekom, en liedjies soos 'Hou my vas, korporaal' van James Phillips (Bernoldus Niemand) het kultusstatus verkry."

102 S. Segerman, Fresh Music: SA artists. James Phillips, 2000. www.rock.co.za/files/james. (Accessed 2007-05-17)

103 S. de Waal, Cherry-faced Lurchers Liner Notes, s.d. www.freshmusic.co.za/cherry (Accessed 2007-05-17)

104 P. Hopkins, Voëlvry, p. 91. 
his contribution was unwitting - limited to sparking an idea in the mind of Ross and creating an album whose greatest impact was its lurid purple cover." 105 This author believes that even within Voëlvry (both the movement and the tour), Phillips was acknowledged, and most importantly by his peers, as far more than a "bit player".

De Waal ${ }^{106}$ also refers specifically to Phillips's "literary gift, married to a supreme musical talent" and the words of Koos Kombuis ${ }^{107}$ - "Dalk moes ek liewer net mooi soppy liedjies ... gesing het en die heavy stuff gelos het vir ander betekenisvolle sangers soos Johannes Kerkorrel en James Phillips" - are indicative of his admiration for Phillips, both as songwriter and singer, as one of those capable of the "heavy stuff".

\section{Conclusion}

"Phillips ... loved South Africa and felt real pain about events and issues in his country." 108 Hopkins attributes to Letoit the opinion: "James wanted a normal career in a normal society. He knew he was talented." ${ }^{109}$ But Phillips also knew that he was living in an abnormal society - so what did he do about it all?

In the University of Pretoria programme for the Autumn Graduation Ceremony 2007, as part of the citation for the honorary doctorate awarded to the Afrikaans author Elsa Joubert, the influence of her 1978 seminal work Die swerfjare van Poppie Nongena ${ }^{110}$ is described as follows:

Die impak van die boek destyds word waarskynlik die beste beskryf deur prof. J.J. Degenaar, die Stellenbosch filosoof: 'Elsa Joubert het veral een groot bydrae tot die Afrikaners se politieke bewuswording gelewer. Sy het dit vir ons onmoontlik gemaak om in die toekoms verontskuldigend te beweer: Maar ons het nooit geweet dat dit die ware toedrag van sake is en dat ons wette werklik so gewelddadig op mense se lewe inwerk nie.'

It can perhaps equally be stated that Phillips made it "vir ons onmoontlik ... om in die toekoms verontskuldigend" to feel that South African rock music could ever be the same as in the pre-Phillips era. Shaun de Waal ${ }^{111}$ described Phillips in an obituary as

105 P. Hopkins, Voëlvry, p. 91.

106 S. de Waal, Cherry-faced Lurchers Liner Notes, s.d. www.freshmusic.co.za/cherry (Accessed 2007-05-17)

107 K. Kombuis, Seks \& Drugs \& Boeremusiek (Kaapstad, 2000), p. 18.

108 K. Shoemaker, Review of Fresh Music: SA artists, 2001.www.rock.co.za/files/jp made (Accesssed 2007-05-17)

109 P. Hopkins, Voëlvry, p. 212.

110 P. Hopkins, Voëlvry, p. 69 refers to the book as "the most influential book to be published at this time." 
"our Bob Dylan ${ }^{112}$... a death which, to many, feels like the end of an era." "113 Phillips's influence was both as an individual musician, and in the context of his bands, and of Voëlvry and (so-called) Alternative Afrikaans music, where he and others such as Johannes Kerkorrel and Koos Kombuis, according to Hopkins, quoting Max du Preez, ${ }^{114}$

... radically shifted the boundary of Afrikaans music. After Voëlvry there was an incredible explosion of new Afrikaans music and, most importantly, good Afrikaans rock. Voëlvry paved the way for Karen Zoid, Disselblom, Beeskraal, Fokofpolisiekar, Rooibaard and the other great Afrikaans groups currently on the scene. ${ }^{115}$

This influence on musicians who followed him is but one aspect of Phillips's legacy - the interest in him, both academic and otherwise, a dozen years after his untimely death is another clear tribute. Accepting that Phillips was a product of his particular lifetime in South Africa is one thing ("viciously anti-establishment", according to Van $W y k 7^{116}$ ), but also accepting his consciousness of the value of his formal music studies is another, highly relevant aspect in his case. Retired Wits academic Kathy Primos ${ }^{117}$ remembers Phillips "with great affection", describing him as "a very solid chap", with "very solid values", in addition to being a "wonderful character; full of good humour." 118 She also remarked on the fact that he was "so supportive of Music

111 S. de Waal, Rich legacy of a rock'n'roll life, Mail \& Guardian Review 4-10 August 1995, p. 28.

112 Interestingly, Pretorius (W. Pretorius, Kerkorrel, p. 8) also describes Johannes Kerkorrel as "die Bob Dylan van Afrikaanse musiek." Kevin Davidson, though, is the only fellow-musician I found who compared Phillips to the legendary Frank Zappa, and that particularly in connection with Phillips's writing for brass instruments. Davidson (telephonic interview 2007-07-31) noted that although the music might have been difficult to play, it always felt natural for the performers - a clear tribute to Phillips's orchestration skills.

113 P. Hopkins, Voëlvry, p. 216.

114 P. Hopkins, Voëlvry, pp. 206-207.

115 In his chapter in C. Gardner's book Media, politics and culture: A Socialist view (London, 1979), Rosselson uses as his title the question: "Pop music: mobiliser or opiate?" In the case of Phillips's music, the influence was clearly the former, as a mobiliser, and definitely not as an opiate.

116 Personal email correspondence, 2007.

117 Telephonic interview, 2007-07-17.

118 Apart from the many references to Phillips's biting satire and sarcasm, people do also remember him for gentle humour and a sense of fun. His fellow Wits student, Julian Begg (email correspondence 2007-07-26) wrote the following: "James slipped an LP cover of his under the examiner's door in lieu of a written thesis. One presumes that this is not apocryphal and that it happened. Needless to say, the LP cover was found to be wanting even of only in terms of university regulations regarding thesis submission! To my mind, it encapsulates an 
Education", and that is a specific view not expressed as directly by anyone else this author has encountered.

If it is true that "Die gemiddelde rakleeftyd van 'n popster wat pal in die openbare oog is, is drie jaar ... Dan begin die mistiek om hom en sy musiek verdwyn en begin die aanhangers gewoonlik ander rock-engele soek," ${ }^{119}$ then Phillips has proved remarkably hardy, even in death, with his influence stretching unabated over close on 20 years, despite the negative remarks of some authors about the extent of his decline, before his death.

Writing about Johannes Kerkorrel, Pretorius describes him as an "Afrikaanse kunstenaar wat maak dat ons nie meer skaam hoef te voel oor ons musiek nie."120 Phillips can also be described as an artist who ensured that South Africans (not only Afrikaners) 'no longer have to feel ashamed of our music'. Pretorius also notes: ${ }^{121}$ "Dis 'n onbesonne daad om die lewe van 'n rock-en popster ... te probeer dokumenteer ... Want, anders as ander openbare figure, word kunstenaars se lewens nie so presies gekarteer nie omdat hulle wêreld - en veral die musiekwêreld - inherent onstabiel is".

This article has not attempted merely to document the life of James Phillips, but to fathom his musical identity/identities. DeNora describes identity as "a resource for the identification of knowing who you are." 122 In the Introduction it was suggested that "for him it seemed mostly a question of developing his own music, gathering others around him, forming bands and having a positive influence." Phillips was a leader - and he realised his abilities in this regard. He may be labelled as a catalyst, ${ }^{123}$ even if it was not his specific intention to be such. It is clear from Pavlicevic ${ }^{124}$ that identity is a complex notion and never fixed - musically, or otherwise. Nevertheless, the contention can confidently be made that South Africa would have been

\footnotetext{
'outside the box' way of thinking that was James Phillips aka Bernoldus Niemand. Then of course there were those damn street pole stickers all over Braamfontein at the time, which read as follows; 'Wie is Bernoldus Niemand?' not necessarily in (sic) capitalised either. They intrigued many of us and the question remains to this day as to who he really was ... an enigma to many and a dear friend to others." This incident is not apocryphal?? as confirmed by Carl van Wyk, in personal email correspondence.

19 W. Pretorius, Kerkorrel, p. 8.

20 W. Pretorius, Kerkorrel, p. 8.

21 W. Pretorius, Kerkorrel, p. 10.

122 T. DeNora, Music in everyday life, p. 57.

123 L. Hagen, Kulturele identiteit, p. 22: “'n katalisator vir Alternatiewe Afrikaanse Musiek”.

124 M. Pavlicevic, Groups in music (London, 2003), p. 193.
} 
considerably poorer without Phillips in his various guises, let alone his developing identities [Fig. 3].

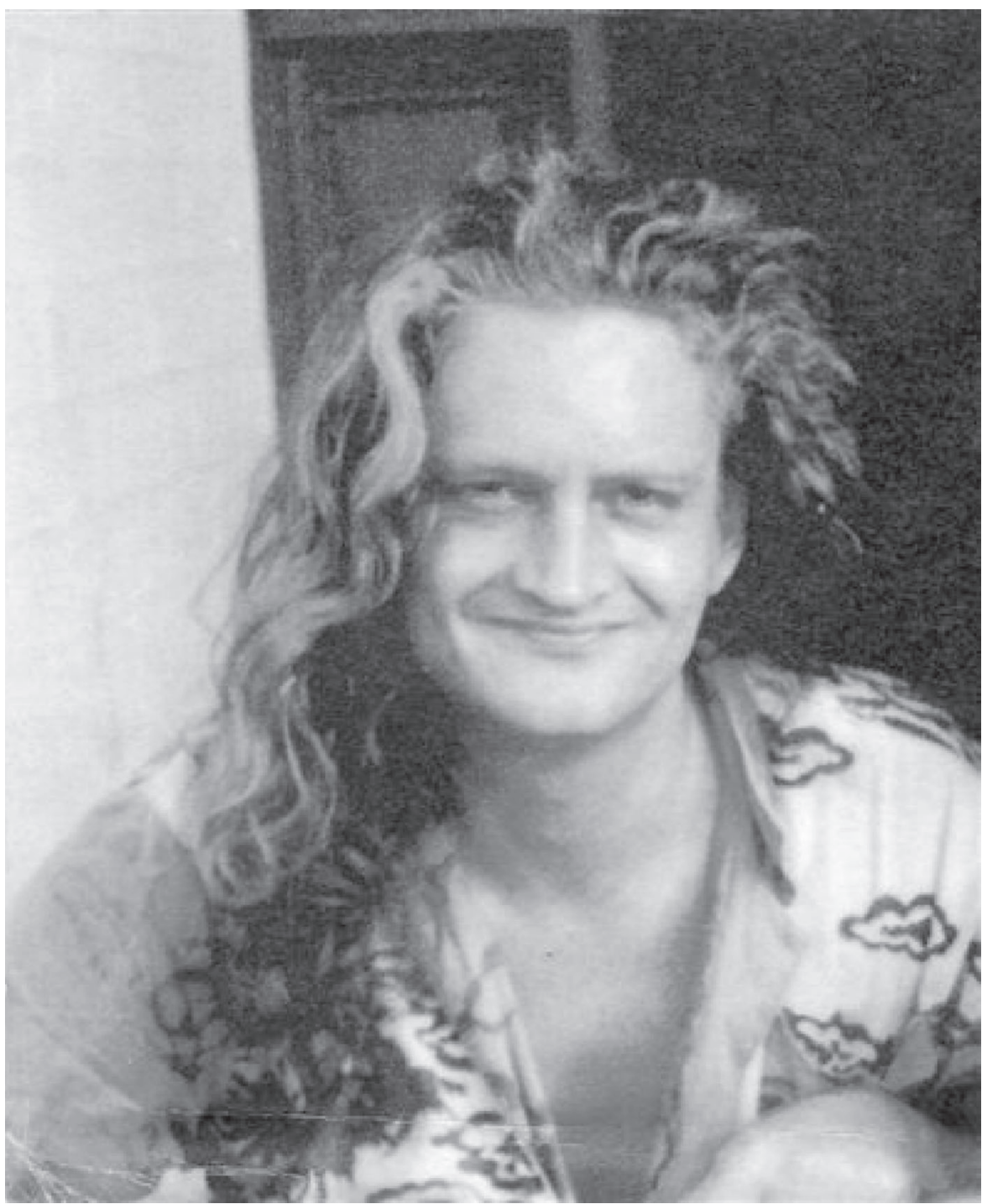

Figure 3: James Phillips

(Photograph: Win Phillips) 